\author{
Sylwia Nessler \\ (D) https://orcid.org/0000-0002-6882-2372 \\ Uniwersytet Papieski Jana Pawła II w Krakowie
}

\title{
Solidarność celebrytów wobec kandydatów na prezydenta USA
}

https://doi.org/10.15633/9788374389952.12

Podczas ostatnich wyborów prezydenckich w USA można było wyraźnie zaobserwować, że gwiazdy amerykańskie mają tendencję do obstawiania jednej ze stron. W kraju światopoglądowo równie bardzo podzielonym jak Polska wybory zawsze są dużym przedsięwzięciem i momentem do deklarowania swoich poglądów, mówienia o nich głośno i zachęcania innych do ich podzielania. W przypadku zwykłego, szarego człowieka tego typu akcje jednak nie mają tak wielkiej i jednocześnie sprawczej mocy jak w przypadku celebrytów, którzy mają tłumy fanów gotowych ślepo za nimi podążać w kwestii poglądów politycznych, także. Ponadto osoby takie, dzięki swoim zasięgom, fizycznie są w stanie dotrzeć do większej liczby osób i być może przekonać ich do swoich racji. Dlatego właśnie temat solidarności celebrytów wobec kandydatów na prezydenta USA wydaje się tak istotny.

Aktywność polityczna celebrytów jest szczególnie widoczna w okresie wyborów, kiedy to media bez wytchnienia odnotowują każde wystąpienie i każdy etap kampanii wyborczej kandydatów, pokazując także zdjęcia owych kandydatów w towarzystwie gwiazd muzyki, sportu, filmu itp. Czy tego rodzaju reklamy mają szansę coś znaczyć? Wielu z badaczy zjawisk społecznych zadało sobie tego rodzaju pytania. Garthwaite i Moore w 2008 roku skupili się na wpływie reklamy, jaką Oprah zagwarantowała prezydentowi Barackowi Obamie podczas wyborów prezydenckich w 2008 roku, dochodząc do wniosku, że „[to wystąpienie] miało statystyczne i polityczne znaczenie dla Obamy”. Odkryto, że w regionach, w których można było znaleźć więcej fanów Oprah, Barack Obama cieszył się większym poparciem, co zostało nazwane „efektem Oprah”. Badania wykazały także, że chociaż ta reklama nie miała wpływu na to, ilu respondentów lubiło Baracka Obame, 
to jednak znacznie zmieniło się ich postrzeganie Obamy jako kandydata i znacznie bardziej postrzegali go jako kandydata, który jest skłonny wygrać wybory. Efekt ten jednakże był jedynie ograniczony do tych osób, które miały bardzo silnie pozytywne zdanie o Oprah ${ }^{1}$. W 2012 roku Anthony J. Nownes przeprowadził badanie, które miało na celu wskazać efekt wsparcia celebrytów na partie polityczne w Stanach Zjednoczonych. Badanie ankietowe zostało przeprowadzone na grupie ponad 500 respondentów. Założenie, jakie przyjął autor badania, było takie, że wsparcie celebrytów dla partii politycznej i ich aktywność polityczna w realny sposób oddziałuje na poglądy polityczne zwykłych obywateli, ma znacznie większy wpływ niż indywidualne wybory każdego z nas. Wyniki, jakie otrzymał, wsparły owe założenie, wskazując na to, że aktywność polityczna celebrytów faktycznie jest w stanie rzutować na poglądy polityczne wielu obywateli ${ }^{2}$.

W jednym z badań przeprowadzonych w 2007 roku politolog David Jackson odkrył, że muzycy, którzy są także celebrytami, są w stanie wpłynąć na nastawienie polityczne oraz opinie swoich fanów w kwestiach politycznych. Celebryci, którzy są znani ze swojej historii politycznego aktywizmu, są szczególnie wpływowi w tej kwestii ${ }^{3}$. W innym badaniu Jackson i Darrow (2005) wskazują, że popularni celebryci mogą przyczyniać się do zmiany poglądów politycznych młodych ludzi ${ }^{4}$. Oczywiście nie wszystkie z przeprowadzonych badań wskazują na takie zależności, ponieważ istnieją też takie, które wskazują na bardzo mały wpływ celebrytów na wybory polityczne ich fanów - według tych badań najważniejszymi czynnikami stają się uwarunkowania personalne oraz wpływ rodziny ${ }^{5}$. Moim jednak zdaniem wybory polityczne celebrytów, czyli osób, do których wiele z nas lubi się porównywać, traktując wręcz ich niekiedy jako autorytety w pewnych dziedzinach życia lub wzory do naśladowania, mają autentyczny wpływ na to, jak postrzegamy danego kandydata. Nie są oczywiście gwarancją sukcesu, zaślepiając nas zupełnie, aczkolwiek słuchając pochlebnych opinii o danym kandydacie

1 Pew Research Center for the People \& the Press; The Oprah Factor and Camapign 2008, https:// www.pewresearch.org/politics/2007/09/20/the-oprah-factor-and-campaign-2008/ (7.04.2021).

2 A. J. Nownes, An experimental investigation of the effect of celebrity support for political parties in the United States, „American Politics Research” (2012) no. 40 (3), s. 476-50o.

3 D. J. Jackson, Selling politics: The impact of celebrities' political beliefs on young Americans, "Journal of Political Marketing" 6 (2007), s. 67-83.

4 D. J. Jackson, T. I. A. Darrow, The influence of celebrity endorsements on young adults' political opinions, „Harvard International Journal of Press/Politics” 10 (2005), s. 80-98.

5 N. T. Wood, K. C. Herbst, Political starpower and political parties: Does celebrity endorsement win first-time votes?, „Journal of Political Marketing” (2007) no. 6, s. 141-158. 
na prezydenta, sami zaczynamy się zastanawiać, czy może faktycznie są one prawdziwe. Wiele osób, może się zastanawiać, czy solidarność, o której mowa, jest prawdziwa. Pytanie, czy możemy tutaj mówić o bezinteresownej solidarności celebrytów względem kandydatów na prezydenta? Po wnikliwej analizie jestem w stanie stwierdzić, że owszem. Gwiazdy zazwyczaj popierają kandydatów o poglądach i przekonaniach, które same wyrażają. Jest to pewnego rodzaju solidarność, która łączy ich właśnie dlatego, że są zwolennikami konkretnego dialogu oraz takich samych postulatów. Oczywiście, zawsze jest druga strona medalu i można stwierdzić, że tak naprawdę nie wiemy, czy poparcie nie jest podyktowane chęcią czerpania korzyści majątkowych po ewentualnej wygranej kandydata. Z biegiem lat można zaobserwować w USA tendencję do solidaryzowania się większości celebrytów z kandydatami, którzy są bardziej liberalni w swoich poglądach. Solidarność gwiazd mogliśmy obserwować podczas ostatnich wyborów prezydenckich w USA, kiedy to wielu celebrytów zabrało głos w kwestii: Joe Biden czy Donald Trump? Kilka przykładowych takich wypowiedzi w social mediach, takich jak Twitter, zostało zacytowanych poniżej.

Znalazła się również spora grupa sław, która głosowała za reelekcją Trumpa podczas wyborów prezydenckich. Do jednego z nich, należących jednocześnie do bardziej znanych, należy 50 Cent, amerykański raper. Zdecydowana większość jednak wyrażała otwarcie swoje poglądy, które szły bardziej w parze z kandydaturą Bidena - wielu z nich zaangażowało się nawet w kampanię prezydenta, fizycznie lub finansowo go wspierając. W social mediach pojawiły się liczne wpisy, które miały na celu otworzyć oczy obserwatorom gwiazd na to, dlaczego wybierają akurat tego kandydata i w jaki sposób ten drugi jest dla nich bezwartościowy. Zdania były podzielone, ale trudno było znaleźć bezstronne osoby w tej sytuacji ${ }^{6}$.

Rozpoczynając od celebrytów, którzy wspierali Donalda Trumpa, warto w pierwszej kolejności także poruszyć kwestię tego, dlaczego w ogóle to robili? Wiadomo, że dla wielu jego prezydentura była mocno kontrowersyjna. Jednak mimo wszystko, wbrew temu, co często przekazuje się w mediach, Donald Trump ma duże poparcie w Ameryce. Jego przegrana nie była wielką porażką. Do końca liczenia głosów w poszczególnych Stanach nie było pewne, który z kandydatów wygra - walka była więc wyrównana, chociaż

6 G. Shaw, 35 celebrities who have revealed who they are voting for this year, https://www.insider.com/ celebrities-supporting-2020-election-2020-10 (13.05.2021). 
media przekazywały informacje korzystne dla Bidena. Warto zatem zgłębić się w treść argumentów, jakie podnosili celebryci, namawiając do głosowania na Trumpa oraz demonstrując własne poglądy.

Scott Baio, gwiazda popularnego amerykańskiego sitcomu, zapytany - po wycieku sławnych taśm o Trumpie mówiącym w seksistowski sposób o kobietach - dlaczego wspiera Trumpa, odpowiedział: „Trump nie jest politykiem, mówi jak każdy z nas, a kobiety - to jest to, o czym każdy koleś rozmawia, kiedy nie ma ich w pobliżu. Więc jeśli czujesz się przez to urażony, dorośnij. Tak funkcjonuje świat, to nie jest jakaś wielka rzecz"7. Baio także opublikował serię tweetów na Twitterze, zachęcając swoich obserwujących do głosowania na Donalda Trumpa. Kirstie Alley, amerykańska aktorka i scenarzystka, ogłosiła że wcześniej głosowała na Baracka Obamę, teraz natomiast ma w planach głosować na Trumpa. Opublikowała na swoim Twitterze listę polityków, na których głosowała w poprzednich wyborach. Miesiąc później zwiększyła swoje wsparcie, publikując wpis o treści: „Głosuję na Donalda Trumpa, ponieważ on NIE JEST politykiem. Głosowałam na niego 4 lata temu dla tego samego powodu i znów na niego zagłosuję. Realizuje wszystkie sprawy szybko i przywróci ekonomię do sprawnego działania równie szybko. Proszę bardzo" ". Jednocześnie gwiazda kłóciła się z innymi użytkownikami Twittera, którzy krytykowali ją za poglądy oraz czynienie swojej kariery znów „istotnej”, wykorzystując rozgłos dany jej przez wspieranie Trumpa, na co odpowiedziała: „Uwierzcie mi, ostatnie słowa, które usłyszycie w Hollywood będą brzmiały: «Steven kochanie, łap za tą listę osób głosujących na Trumpa! Ściągnij ich tutaj i dajmy im wszystkim pracę!»”, ewidentnie wyśmiewając owe uwagi. Brett Favre, twórca Narodowej Ligi Futbolowej (NFL), także wyrażał swoje wsparcie dla Trumpa, pisząc: „Mój głos jest dla czynienia tego kraju wspaniałym, dla wolności słowa i religii, ciężkiej pracy obywateli płacących podatki, policji i wojska. W tej elekcji mamy wolność wyboru, którą wszyscy powinniśmy uszanować. Według mnie i względem tych zasad, ten głos jest dla Donalda Trumpa"10. Podobnie raper Lil Wayne

7 O. Blair, Scott Baio defends Donald Trump's sexist comments: "Ladies, this is what guys talk about when you're not around", https://www.independent.co.uk/news/people/donald-trump-scott-baiocomments-response-sexism-ladies-guys-a7354021.html (15.05.2021)

8 Oficjalny profil na Twitterze: Kirstie Alley, https://twitter.com/kirstiealley/status/1317603908009721868 (15.05.2021).

9 Tamże.

10 Oficjalny profilna Twitterze: Brett Favre, https://twitter.com/brettfavre/status/1322154221584732163 (15.05.2021). 
wyraził swoje wsparcie dla tej kandydatury: „Właśnie miałem niezwykłe spotkanie z Donaldem Trumpem, poza tym, co uczynił dla reformy kryminalnej, plan platynowy zamierza przynieść społeczeństwu prawdziwe prawo własności. Słuchał tego, co miałem mu dzisiaj do powiedzenia i zapewnił mnie, że może to zrobić i to zrobi" ${ }^{\prime \prime}$.

Na podstawie tych wpisów na Twitterze można wywnioskować, że osoby popierające Trumpa to konserwatyści. Trump odnalazł wsparcie także wśród osób, które uważały, że Ameryka potrzebowała „zrobić porządek” z wieloma sprawami - dość twardą ręką. Tego byłemu prezydentowi nie można odmówić - podejmował decyzje stanowcze, niekiedy takie, które wielu się nie podobały, bez mrugnięcia okiem. Mówi się także, że znacznie bardziej niż dotychczasowi prezydenci wspierał „zwykłych ludzi”, skupiając się na własnym narodzie, a mniej na dyplomacji. Tak jak Donald Trump posiadał sporą liczbę osób, które go wspierały oraz aprobowały prowadzoną przez niego politykę, w podobnej sytuacji znalazł się także Joe Biden. Można zaobserwować, że Trumpa popierały gwiazdy, które już czasy świetności mają za sobą. Osoby, które głosowały na aktualnego prezydenta Stanów Zjednoczonych, miały ewidentnie dość polityki prowadzonej przez byłego prezydenta, uznając ją za bezsensowną i agresywną, odległą od myśli o Ameryce jako o kraju wyboru i równości wśród obywateli. Wielu z muzyków wyraziło swoje wsparcie dla Partii Demokratycznej, występując w sposób wirtualny na Narodowej Konwencji Demokratycznej, która odbyła się 17 sierpnia. W ciągu czterech dni artyści tacy jak: Billie Eilish, John Legend, The Chicks, Common, Jennifer Hudson i wielu innych występowali, wspierając tym samym kandydaturę Bidena. Beyonce na swoim Instagramie zamieściła zdjęcie z naklejką „zagłosowałam”, jednocześnie mając na twarzy maseczkę ochronną z kampanią Biden/Harris 2020. Lebron James na Instagramie opublikował wpis: „Jeszcze jeden dzień. Proszę. Musimy zmienić WSZYSTKO, a to wszystko zaczyna się jutro"12. Taylor Swift, amerykańska wokalistka oraz autorka tekstów piosenek, ogłosiła swoje wsparcie dla Joe Bidena oraz Kamali Harris w social mediach. Razem ze zdjęciem okładki magazynu „V Magazine” i ujęciem, na którym widać, że trzyma ciasteczka z napisem „Biden Harris 2020”, kobieta napisała: „Rozmawiałam z @vmagazine na temat tego, dlaczego będę

11 S. Dodd, Find Out Which Presidential Candidate These Celebrities Are Supporting, https://people. $\mathrm{com} /$ politics/2020-election-presidential-candidate-celebrities-voting-for/ (15.05.2021).

12 Oficjalny profil na Instagramie: Lebron James, https://www.instagram.com/p/CHHLZj1AGkY/c/18134167204181420/ (25.06.2021). 
głosowała na Joe Bidena jako na prezydenta”. W artykule natomiast padają słowa: „Zmiana, której najbardziej potrzebujemy to wybrać prezydenta, który wie, że ludzie koloru zasługują na to, aby czuć się bezpiecznie i być reprezentowani, że kobiety zasługują na to, aby mieć wybór decydowania, co stanie się z ich ciałami, a społeczność LGBTQIA+ zasługuje na to, żeby być dostrzegana i brana pod uwagę"13. Dodaje także: „Każdy zasługuje na rząd, który traktuje poważnie globalne zagrożenia zdrowia publicznego i na pierwszym miejscu stawia życie ludzi”.

Jennifer Lawrence, gwiazda m.in. Igrzysk śmierci, także rozmawiała z dziennikarzem magazynu „V Magazine”, wyraziła na jego łamach swoje wsparcie dla prezydenta Joe Bidena i senator Kamali Harris. „Głosuję w tym roku na Joe Bidena i Kamalę Harris, ponieważ Donald Trump do tej pory stawiał siebie ponad bezpieczeństwo i dobre funkcjonowanie Ameryki i będzie nadal to robił”"14, powiedziała Lawrence. Dodała także: „Nie reprezentuje on ważnych dla mnie wartości jako Amerykanki i, przede wszystkim, jako istoty ludzkiej"15. Ponadto aktorka zauważyła, że głosowanie jest fundamentem naszej demokracji oraz naszej wolności, zaznaczyła także, że postrzega te wybory jako najbardziej istotne i niosące najważniejsze konsekwencje ${ }^{16}$. Ina Garten, gwiazda Food Network, zaznacza: „Nie jestem politykiem. W momencie, kiedy zrobisz research, zorientujesz się, że prywatnie wspierałam kilka programów politycznych, jednakże nigdy nie odnosiłam się do polityki publicznie - ale czasem trzeba to zrobić. Jako kraj, musimy działać razem. Musimy przestać się dzielić, a zacząć się wspierać, być pozytywni i współpracować. Biden jest człowiekiem, który jest w Kongresie od dekad i ma reputację osoby pracującej także w okresach przejściowych i myślę, że to tego dokładnie w tym momencie potrzebujemy"17. Jim Gaffigan, komik, podjął decyzję otwartego zadeklarowania swoich poglądów, które wymierzone miały być przeciwko Trumpowi: „Szczerze, w tym momencie czuję, że nie mam innej opcji. Myślę, że Trump próbuje i możliwe, że już zrujnował, mój kraj.

13 Oficjalny profil na Twitterze: Taylor Swift, https://twitter.com/taylorswift13/status $/ 1313938080290803715$ (25.06.2021).

14 J. Juneau, Jennifer Lawrence Endorses Joe Biden and Kamala Harris: Trump "Does Not Represent My Values", https://people.com/movies/jennifer-lawrence-endorses-joe-biden-kamala-harrispresidential-election-2020/ (25.06.2021).

15 Tamże.

16 Tamże.

17 S. Spence, Ina Garten Is Hosting a Fundraiser for Joe Biden's Campaign: "We Need to Stop Being Divisive”, https://people.com/food/ina-garten-hosting-fundraiser-for-joe-biden-campaign/ (25.06.2021). 
[...] Czuję odpowiedzialność w stosunku do kolejnych generacji, moich dzieci, samolubnie nie chcę mówić moim wnukom, że nie walczyłem, aby powstrzymać Trumpa. Może zrozumieją, że stanąłem za przyzwoitością, prawem i równością. Może przez wyjście z mojej strefy bezpieczeństwa mogę pomóc w zainspirowaniu tych, którzy boją się zrobić to, co już czują, że jest słuszne i rozważyć, na kogo i na co właściwie głosują, bez poczucia, że nie mają innego wyboru niż głosować na Trumpa. Czy zrobiłem jakąś różnicę? Nie wiem"18. Ciekawej wypowiedzi na Narodowej Konwencji Demokratycznej udzieliła Julia Louis Dreyfus: „Kilka lat temu, został u mnie zdiagnozowany nowotwór i byłam absolutnie przerażona. Jedną z pierwszych osób, które do mnie wtedy zadzwoniły był Joe. Jego prawdziwe ciepło i uprzejmość podczas tego telefonu, muszę przyznać, sprawiły, że się rozpłakałam"19. Później zażartowała, że przeciwnik Bidena, Donald Trump, sprawił, że płakała z innych powodów. „Nasz obecny prezydent też sprawił, że płakałam, ale to nie miało nic wspólnego z jego ciepłem i uprzejmością. Empatia Joe Bidena jest prawdziwa. Możesz to odczuć. To dlatego prezydent Obama poprosił Joe, żeby stanął na czele Cancer Moonshot. Prezydent Obama wie to, co my wszyscy wiemy - Joe Biden rozumie cierpienie, stratę i poświęcenie"20. Michelle Kwan, olimpijska łyżwiarka, wspierała Joe Bidena od dłuższego czasu. Swoim entuzjazmem co do jego kandydatury na prezydenta USA podzieliła się w poście na Instagramie: „Jestem zachwycona, że @Joebiden ogłosił, że kandyduje na Prezydenta. Wierzę, że wiceprezydent jest idealnym kandydatem na zjednoczenie naszego kraju ze swoim doświadczeniem, wiedzą i chęcią walki dla Amerykanów. Co ważniejsze, reputacja wiceprezydenta Bidena opiera się na tym, że załatwia on wszystkie istotne sprawy - od realizacji najbardziej wszechstronnych i postępowych inwestycji w narodową infrastrukturę i firmy wspierające naturalną energię, do pisania Aktu Przemocy Wobec Kobiet i wygrania (dwukrotnego) NRA. Jest kandydatem, którego wspieram z dumą, ponieważ on zrobi to, co będzie trzeba, aby przywrócić duszę temu narodowi, odbudować kręgosłup tego kraju oraz zjednoczyć Amerykę"21 . Aktor Dwayne

18 B. VanHoose, Jim Gaffigan Says He Spoke Out Against Trump Because "I Feel a Responsibility to Coming Generations”, https://people.com/politics/jim-gaffigan-says-he-received-threats-after-viraltwitter-rant-against-trump/ (25.06.2021).

19 J. Mazziotta, Joe Biden Was 'One of the First People' to Call Julia Louis-Dreyfus After Her Cancer Diagnosis, https://nz.news.yahoo.com/joe-biden-one-first-people-154235861.html (25.06.2021).

20 Tamże.

21 H. Murphy, Former Olympic Figure Skater Michelle Kwan Is JoiningJoe Biden's Presidential Campaign, https://people.com/politics/michelle-kwan-joining-joe-biden-campaign/ (25.06.2021). 
Johnson ogłosił swoje wsparcie dla prezydenta Bidena w filmie udostępnionym na jego kanale na YouTube. Na tym wideo widać jak Dwayne odbywa wideokonferencję z Bidenem i Kamalą Harris. „Byłem szczęściarzem przez ostatnie lata, w swoim życiu i w swojej karierze będąc częścią i uczestnikiem pewnych wielu ważnych, definiujących momentów, i nigdy publicznie nie wspierałem kandydata na prezydenta ani wiceprezydenta, przez całą swoją karierę, w całym swoim życiu ${ }^{22}$ ", zaznaczył aktor, zanim publicznie ogłosił swoje wsparcie dla Bidena i Harris. Prezydent Joe Biden, dziękował za jego wsparcie. Katherine Schwarzenegger napisała na Instagramie, w odpowiedzi na bagatelizowanie przez Donalda Trumpa swoich pozytywnych wyników na koronawirusa oraz pandemii samej w sobie: „Jeśli ten tweet nie jest wystarczającym powodem, aby chcieć wybrać Bidena i pozbyć się Trumpa ze stanowiska prezydenta naszego kraju, to nie wiem, co nim jest" ${ }^{23}$. Schwarzenegger widocznie potępiła także inne wpisy Donalda Trumpa, wskazujące na to, że nie podchodził on z należytą ostrożnością do swojej choroby oraz problemu pandemii. Dodała także: „Zawsze byłam kimś, kto podchodził bardzo z szacunkiem dla wyboru ludzi, co do tego, kogo wspierają, zwłaszcza politycznie. Dorastałam w rodzinie, gdzie były różne preferencje polityczne, więc przywykłam do tego i podchodzę do tego z szacunkiem. Teraz jednak jestem w takim punkcie, że kiedy myślę o interakcji z kimś, kto wspiera mężczyznę, który twierdzi, że podczas gdy są ludzie, którzy stracili ukochanych i którzy są naprawdę chorzy oraz ci, którzy ciągle «umierają na COVID», to naprawdę nie rozumiem, jak można wspierać tego rodzaju osobę. Naprawdę, zacznijcie myśleć, ludzie"24.

Jakby spojrzeć na to, czym charakteryzowali się celebryci wspierający Bidena, to na usta ciśnie się odpowiedź, że „niechęcią do Trumpa”. Każda z tych osób była widocznie zniesmaczona tym, jak bardzo Ameryka stała się podzielona za sprawą prezydentury Donalda Trumpa oraz jak sama polityka tego prezydenta wyglądała. Niejednokrotnie zarzucano mu rasizm oraz szowinizm, z których to oskarżeń niekiedy trudno było mu się wybronić - po

22 K. Willis, Dwayne Johnson backs Joe Biden, Kamala Harris, his first presidential endorsement, https://eu.usatoday.com/story/entertainment/celebrities/2020/o9/27/dwayne-johnson-backsjoe-biden-kamala-harris-first-presidential-endorsement/3554377001/ (25.06.2021).

23 K. Justich, Katherine Schwarzenegger urges followers to vote for Joe Biden after Donald Trump tells Americans "Don't be afraid of COVID", https://www.yahoo.com/entertainment/katherineschwarzenegger-urges-followers-vote-joe-biden-205711527.html (25.06.2021).

24 S. Dodd, Find Out Which Presidential Candidate These Celebrities Are Supporting, https://people. $\mathrm{com} /$ politics/2020-election-presidential-candidate-celebrities-voting-for/ (15.05.2021). 
sieci bowiem krążyły jego wypowiedzi, które faktycznie miały mocno negatywny wydźwięk. Jednakże nie można powiedzieć, że Joe Biden przekonał do siebie wyborców tylko tym, że po prostu nie był Trumpem. Wiele osób zdecydowało się oddać na niego głos ze względu na to, jak bardzo doświadczonym był on człowiekiem oraz jak bardzo wspierał równość i jakiego udzielał wsparcia ludziom różnych narodowości oraz kobietom, szczególnie tym, które były ofiarami napaści na tle seksualnym czy przemocy domowej. Ponadto dla wielu wydaje się on osobą, która może w końcu zjednoczyć Amerykę, sprawić, że ta znów stanie się całością i krajem, w którym celebruje się wolność i równość, a nie sfrustrowanym, podzielonym na pół narodem.

Analizując poparcie celebrytów dla Trumpa oraz dla Bidena, dość łatwo można zaobserwować, że na tego drugiego Hollywood głosowało częściej. Solidarność, jaką można było obserwować na Twitterze, Instagramie i innych mediach społecznościowych, była imponująca. Wydawać by się mogło, że cała Ameryka żyła tymi wyborami, trzymając kciuki za to, aby urząd prezydenta Stanów Zjednoczonych pełnił ktoś inny niż dotychczasowy prezydent. Osoby z dużymi zasięgami w social mediach otwarcie nawoływały do wybrania „odpowiedniego” kandydata, brały udział w licznych kampaniach, wyrażały swoje zdanie w otwarty sposób. To z kolei w dużym stopniu odwołuje się do psychologicznej reguły autorytetu.

Reguła autorytetu jest jedną z zasad wpływu społecznego, wyróżniona została przez Roberta Cialdiniego, profesora psychologii Uniwersytetu Stanowego w Arizonie. W dużym uproszczeniu polega ona na tym, że człowiek charakteryzuje się większą uległością i skłonnością do posłuszeństwa wobec osób, które uważa się za autorytety. Niekiedy ulega się także atrybutom wysokiego statusu, koncentrując się na pozamerytorycznej wartości przekazu. Ludzie bowiem w sposób naturalny zwracają uwagę na to, kto i jak mówi, niejednokrotnie zupełnie ignorując to, o czym mówi. Jakby na to nie patrzeć, cały proces socjalizacji polega na tym, że uczy się nas posłuszeństwa - wobec nauczycieli, rodziców, lekarzy, opiekunów itp. Nie dziwi więc nikogo uległość pracownika wobec pracodawcy czy żołnierza wobec dowódcy armii. Uleganie sugestiom autorytetu odbywa się na poziomie bodziec-reakcja, to znaczy niekiedy nawet poza naszą świadomością. Autorytet lidera grupy wydaje się niezbędny, kiedy spojrzeć na tę kwestię z szerszej perspektywy w najprostszym ujęciu, zapobiega on anarchii ${ }^{25}$. 
Wartym uwagi przykładem na to, jak silna staje się uległość wobec autorytetu, jest eksperyment Milgrama. Oficjalnie eksperyment ten został przeprowadzony, aby wykazać zmiany w umiejętności zapamiętywania nowych słów pod wpływem impulsów elektrycznych, które charakteryzowały się coraz większym napięciem. Ochotnicy do tego eksperymentu pełnili rolę asystenta profesora i słuchali jego poleceń - aplikowali impulsy elektryczne osobie, która nieprawidłowo zapamiętała dane słowo. Tak naprawdę jednak prąd był wyłączony, a osobą, która miała zapamiętywać słowo, był aktor, który miał symulować konwulsje i drgawki następujące po podaniu prądu. Faktycznym celem badania była odpowiedź na pytanie: „Jak daleko ludzie się posuną, aby spełnić sugestie i polecenia autorytetu?”. Wnioski były szokujące - grymasy bólu, krzyki i żądanie przerwania badania nie wywołały $\mathrm{u}$ asystentów buntu wobec poleceń profesora ${ }^{26}$.

W kontekście niniejszego eseju można wnioskować z tego eksperymentu, że osoby, które mają się za prawdziwych fanów gwiazd wyrażających swoje otwarte poparcie dla któregoś z kandydatów na prezydenta, mogą ulec ich nawoływaniu, aby na niego głosować - ze względu na uległość autorytetowi. Ponadto dość naturalne jest, że kiedy posiadamy jakiś wzór, chcemy go po prostu naśladować w każdej kwestii, także poglądów i przekonań politycznych. To właśnie dlatego solidarność celebrytów wobec kandydatów na prezydenta USA miała, ma i będzie miała takie znaczenie. Jedna osoba posiadająca miliony obserwujących może część z nich przekonać do swojego zdania. W momencie, kiedy tych osób jest jeszcze więcej, szanse na sukces stają się proporcjonalnie większe. Spory wpływ na ogólny nastrój wokół wyborów ma również zamieszanie wokół jednego z prezydentów - to znaczy przedstawianie go w takim świetle, jakoby był on wymarzonym kandydatem na prezydenta. Ludzie, ciągle bombardowani tego rodzaju stwierdzeniami, wkrótce podświadomie zaczną myśleć w ten sposób, a tego rodzaju rozumowanie jest dobre dla każdego polityka.

Najważniejszym narzędziem dla wyrażania solidarności wobec danego kandydata na prezydenta są media społecznościowe. Czy tego chcemy, czy nie, to one budują aktualnie świat wokół nas - budują także nasze postrzeganie tego świata, informacje najczęściej przekazując już w pewien wykalibrowany, bynajmniej nie obiektywny sposób. Najczęściej nie mamy podsuniętych pod nos rzetelnych informacji czy danych - dzisiaj mamy je podane 
zwykle razem z interpretacją, która jest nam implementowana i którą, podświadomie, przyjmujemy za pewnik. Dlatego to, jakiego rodzaju informacje czy serwisy czytamy, ma taki wpływ na nasze ostateczne poglądy. Bombardowani informacjami z lewicowej czy prawicowej perspektywy, podawanymi najczęściej w ścisłej narracji, wkrótce stajemy się osobami nawet nie przyjmującymi do wiadomości, że „ta druga strona” może mieć rację.

Tematem wpływu wsparcia celebrytów dla konkretnego ugrupowania politycznego zajęli się także badacze, którzy trudzą się badaniami nad komunikacją. W badaniu młodych dorosłych w Wielkiej Brytanii Veer, Becirovic i Martin odkryli, że pośród słabo poinformowanych respondentów, wpływ poglądów deklarowanych przez celebrytów jest wielki ${ }^{27}$. Inne badania sugerują, że celebryci są w stanie „połączyć zwykłych obywateli z kwestiami politycznymi”, ponieważ dla wielu celebryci są bardziej godni zaufania niż politycy ${ }^{28}$. W skrócie można powiedzieć więc, że owszem, patrząc na to nawet z najróżniejszych punktów widzenia, wpływ celebrytów na politykę istnieje. Zabiegi, które zastosowano podczas kampanii wyborczych na prezydenta USA, były celowe. Cel był realny do osiągnięcia, ponieważ badania naukowe wskazują na to, że zdanie celebrytów na temat kandydatów na prezydenta z całą pewnością nie pozostaje bez znaczenia.

W świetle tych faktów nic nie ma dziwnego w tym, że to właśnie przez social media celebryci deklarowali swoje poparcie dla konkretnego kandydata na prezydenta oraz namawiali swoich obserwujących, chociaż w sposób pośredni, do zrobienia tego samego. Często ukazywali oni zagłosowanie na konkretnego kandydata jako jedyny słuszny wybór. To znaczy - jeśli nie wybierasz w ten sam sposób, nie zależy ci na twojej ojczyźnie. Jasno zaznaczali, że jeżeli chcesz być w „drużynie” swojego ulubionego aktora czy aktorki, powinieneś głosować na konkretnego polityka. W pewnym sensie każdy z nas to robi - zwykle otaczamy się ludźmi o podobnym spojrzeniu na świat, a więc na politykę także. Namawiamy swoich znajomych do racji, które uważamy za słuszne. Deklarujemy otwarcie swoje zdanie, na Instagramie także. Jednakże większość z nas nie ma takiej siły przebicia swoimi deklaracjami i próbami przekonania innych. Dlatego właśnie osoby sławne mają, jakby na to nie patrzeć, realny wpływ na politykę.

27 E. Veer, I. Becirovic, B. A. S. Martin, If Kate voted conservative, would you? The role of celebrity endorsements in political party advertising, „European Journal of Marketing” 44 (2010), s. 436-450.

28 S. Inthorn, J. Street, "Simon Cowell for prime minister"? Young citizens' attitudes towards celebrity politics, „Media, Culture and Society” 33 (2011), s. 479-489. 
Wybory na prezydenta USA są natomiast ważne dla całego świata. Nie można zapomnieć, że Stany Zjednoczone to potęga gospodarcza, a PKB tego kraju to 21 bilionów dolarów, czyli niemal 1/4 światowego PKB, podczas gdy populacja stanów to zaledwie $4,25 \%$ populacji świata. Ponadto USA to także potęga giełdowa - „gdy Ameryka kichnie, reszta świata ma katar”, zwykło się mówić. Kapitalizacja, czyli giełdowa wartość wszystkich akcji notowanych na giełdach zmienia się co sekundę, ale bez zmian pozostaje czołowa, amerykańska dwójka - NYSE i NASDAQ. Ameryka jest także potęga walutową - od II wojny światowej dolar jest najważniejszą walutą świata i żadna inna nie jest nawet bliska tego statusu. USA nie można także odmówić statusu potęgi militarnej - trudno zakładać, że gdy reszta świata postanowi odwrócić się od dolara, a tego rodzaju głosy da się słyszeć z Rosji czy z Chin, USA pozostanie bierne. Dlatego wybory w USA mają realny wpływ na to, co dzieje się tak naprawdę na całym świecie. Nic więc dziwnego, że nawet $\mathrm{w}$ innych krajach niż Stany Zjednoczone, między innymi w Polsce, słychać było głosy poparcia dla konkretnego kandydata na prezydenta. W dużym stopniu bowiem relacje dyplomatyczne między naszym krajem a prezydentem USA zależeć miały od tego, kto tym prezydentem zostanie. Podczas gdy obecna partia rządząca w Polsce oraz Donald Trump wydawali się podzielać pewne poglądy na wiele spraw, opozycja często apelowała o to, aby wybrać kogoś, kto nie będzie wspierał Prawa i Sprawiedliwości - jak zarzucano - w autorytarnych dążeniach. Swój głos zabrali także polscy celebryci, mając na względzie to, że wybory za oceanem będą miały także realny wpływ na to, co będzie się działo na całym świecie, a więc i w Polsce.

Podsumowując, niniejszy artykuł miał na celu wskazać, jak wielka jest solidarność celebrytów wobec kandydatów na prezydenta USA oraz jaki wpływ owa solidarność ma w szerszym znaczeniu na wybory prezydenckie, z krótkim wyjaśnieniem kilku mechanizmów, które za tym stoją. W ostatnim czasie, obserwując owe wybory, mogliśmy zauważyć, jak wielkim narzędziem są social media, dzięki którym kwestię wyborów udało się maksymalnie nagłośnić. Była to także sprawa, która podzieliła społeczeństwo amerykańskie, przez co przeciągnięcie każdej osoby na swoją stronę wydawało się sprawą ogromnie ważną. 


\section{Bibliografia}

Garthwaite C., Moore T. J., The role of celebrity endorsements in politics: Oprah, Obama, and the 2008 Democratic Primary, 2008, http://www.stat.columbia.edu/ gelman/ stuff_for_blog/celebrityendorsements_garthwaitemoore.pdf (10.09.2021).

Inthorn S., Street J., „Simon Cowell for prime minister”? Young citizens' attitudes towards celebrity politics, „Media, Culture and Society” 33 (2011), s. 479-489.

Jackson D. J., Selling politics: The impact of celebrities' political beliefs on young Americans, „Journal of Political Marketing” 6 (2007), s. 67-83.

Jackson D. J., Darrow T. I. A., The influence of celebrity endorsements on young adults'political opinions, „Harvard International Journal of Press/Politics” 10 (2005), s. 80-98.

Nownes A. J., An experimental investigation of the effect of celebrity support for political parties in the United States, „American Politics Research” (2012) no 40 (3), s. $476-500$.

Ratyński W., Psychologiczne i socjologiczne aspekty zarzadzania, C. H. Beck, Warszawa 2005.

Veer E., Becirovic I., Martin B. A. S., If Kate voted conservative, would you? The role of celebrity endorsements in political party advertising, „European Journal of Marketing" 44 (2010), s. 436-450.

Wood N. T., Herbst K. C., Political star power and political parties: Does celebrity endorsement win first-time votes?, "Journal of Political Marketing 6 (2007), s. 141-158.

\section{Strony internetowe}

Blair O., Scott Baio defends Donald Trump's sexist comments: "Ladies, this is what guys talk about when you're not around», https://www.independent.co.uk/news/people/ donald-trump-scott-baio-comments-response-sexism-ladies-guys-a7354021.html (15.05.2021).

Dodd S., Find Out Which Presidential Candidate These Celebrities Are Supporting, https://people.com/politics/2020-election-presidential-candidate-celebritiesvoting-for/ (15.05.2021).

https://twitter.com/brettfavre/status/1322154221584732163 (15.05.2021).

https://twitter.com/kirstiealley/status/1317603908009721868 (15.05.2021).

https://twitter.com/kirstiealley/status/1318650950970728450 (15.05.2021).

https://twitter.com/taylorswift13/status/1313938080290803715 (25.06.2021).

https://www.instagram.com/p/CHHLZj1AGkY/c/18134167204181420/ (25.06.2021). 
Juneau J., Jennifer Lawrence Endorses Joe Biden and Kamala Harris: Trump «Does Not Represent My Values», https://people.com/movies/jennifer-lawrence-endorses-joebiden-kamala-harris-presidential-election-2020/ (25.06.2021).

Justich K., Katherine Schwarzenegger urges followers to vote for Joe Biden after Donald Trump tells Americans «Don't be afraid of COVID», https://www.yahoo.com/entertainment/katherine-schwarzenegger-urges-followers-vote-joe-biden-205711527.html (25.06.2021).

Krocz K., Reguta autorytetu, https://portal.abczdrowie.pl/regula-autorytetu (17.05.2021).

Mazziotta J., Joe Biden Was 'One of the First People' to Call Julia Louis-Dreyfus After Her Cancer Diagnosis, https://nz.news.yahoo.com/joe-biden-one-first-people-154235861. html (25.06.2021).

Murphy H., Former Olympic Figure Skater Michelle Kwan Is Joining Joe Biden's Presidential Campaign, https://people.com/politics/michelle-kwan-joining-joe-biden-campaign/ (25.06.2021).

Pew Research Center, The Oprah Factor and Camapign 2008, https://www.pewresearch.org/politics/2007/09/20/the-oprah-factor-and-campaign-2008/ (7.04.2021).

Shaw G., 35 celebrities who have revealed who they are voting for this year, https://www. insider.com/celebrities-supporting-2020-election-2020-10 (13.05.2021).

Spence S., Ina Garten Is Hosting a Fundraiser for Joe Biden's Campaign: «We Need to Stop Being Divisive», https://people.com/food/ina-garten-hosting-fundraiser-forjoe-biden-campaign/ (25.06.2021).

VanHoose B., Jim Gaffigan Says He Spoke Out Against Trump Because «I Feel a Responsibility to Coming Generations», https://people.com/politics/jim-gaffigan-says-hereceived-threats-after-viral-twitter-rant-against-trump/ (25.06.2021).

Willis K., Dwayne Johnson backs Joe Biden, Kamala Harris, his first presidential endorsement, https://eu.usatoday.com/story/entertainment/celebrities/2020/o9/27/dwayne-johnson-backs-joe-biden-kamala-harris-first-presidentialendorsement/3554377001/ (25.06.2021).

\section{Abstrakt}

Solidarność celebrytów wobec kandydatów na prezydenta USA

Celem artykułu jest analiza solidarności celebrytów wobec wybranych kandydatów starających się o urząd prezydenta Stanów Zjednoczonych. Kampanie 
wyborcze w USA charakteryzują się nietypowymi cechami, bowiem jest to jedyne państwo, w którym kampania zaczyna się około roku przed datą wyborów. Amerykańskie gwiazdy mają w zwyczaju otwarcie mówić o swoich wyborach i wyraźnie wskazywać swojego ulubionego polityka. Często sami kandydaci nawet nie zabiegają o ich poparcie. Znaczna część celebrytów w trakcie kampanii bierze czynny udział w wiecach, popierając tym samym kandydata i aktywnie angażując się w Internecie. Podczas wyborów zazwyczaj powstają głębokie podziały wśród artystów. Z obserwacji wynika, że celebryci z biegiem lat coraz bardziej partycypują w staraniach o zapewnienie zwycięstwa swojemu kandydatowi. Pytanie, czy rzeczywiście olbrzymie wsparcie celebrytów pomaga wygrać wybory? Nie jest to takie oczywiste, jak mogłoby się wydawać, o ile niektórym kandydatom pomaga - innym szkodzi. Wszystko zależy od tego, w jaki sposób celebryci okazują poparcie, a także, czy jest ono autentyczne. Dzisiaj jest to komunikacja bezpośrednia, możemy obserwować zdjęcia oraz filmy zamieszczane w mediach społecznościowych, przez co największy wpływ celebryci mają na młodych ludzi, czyli na swoich obserwatorów. Siła oddziaływania jest ogromna, bowiem obejmują swym zasięgiem miliony fanów.

Słowa kluczowe

wybory, USA, solidarność, celebryci, politycy, artyści 
